\title{
Penggunaan Regresi Data Panel pada Analisis Indeks Pembangunan Manusia
}

\author{
Limah Olivia Alviani*
}

Prodi Matematika, Fakultas Matematika dan Ilmu Pengetahuan Alam, Universitas Islam Bandung, Indonesia.

*limaholiviaalviani@gmail.com

\begin{abstract}
Human development index is important component to measure the success level in effort to improve the human life quality. This index has three dimensions, they are called the dimensions of health, the dimensions of education, and the dimensions of decent living standards. The health dimension is measured by using life expectancy. The education dimension is measured by using the expected length of schooling and the average length of schooling. Meanwhile, the standard of living is measured using real per capita expenditure in rupiah. This study aims to find the cause that affects the human development index, and the best model is using panel data as a regression method. The results shown that the human development index is influenced by life expectancy, long school expectations, average length of schooling and per capita expenditure. The model used in this study is named fixed effect model with a coefficient of determination of $99.99 \%$, which means that this model is good enough to be used.
\end{abstract}

Keywords: Human Development Indeks, Panel Data Regression, Fixed Effect Model.

\begin{abstract}
Abstrak. Indeks pembangunan manusia yaitu salah satu komponen penting untuk mengukur tingkat keberhasilan dalam upaya meningkatkan kualitas hidup manusia. Indeks pembangunan manusia dibangun dengan tiga dimensi yaitu dimensi kesehatan, dimensi pendidikan serta dimensi standar layak hidup. Dimensi kesehatan diukur menggunakan angka harapan hidup. Dimensi pendidikan diukur menggunakan harapan lama sekolah dan rata-rata lama sekolah. Sedangkan dimensi standar layak hidup diukur menggunakan pengeluaran per kapita riil dalam rupiah. Penelitian ini bertujuan untuk mencari faktor yang mempengaruhi indeks pembangunan manusia dan model yang terbaik menggunakan metode regresi data panel. Hasil yang diperoleh yaitu indeks pembangunan manusia dipengaruhi oleh angka harapan hidup, harapan lama sekolah, rata-rata lama sekolah dan pengeluaran per kapita. Model yang digunakan pada penelitian ini yaitu fixed effect model dengan nilai koefisien determinasinya sebesar 99,99\% yang berarti model ini baik di gunakan.
\end{abstract}

Kata Kunci: Indeks Pembangunan Manusia, regresi data panel, fixed effect model. 


\section{A. Pendahuluan}

\section{Latar Belakang}

Analisis regresi merupakan alat statistik yang memanfaatkan hubungan antara dua variabel atau lebih yang bersifat kuantitatif, sebagai akibatnya salah satu variabel dapat diprediksi dari variabel lainnya. Salah satu pengembangan dari analisis regresi adalah regresi data panel [1]. Pengamatan terhadap perlakuan contohnya pada bidang pendidikan maupun bidang lainnya tidak cukup jika diamati hanya dalam ketika bersamaan saja, perlu dipengaruhi pengamatan dalam beberapa periode waktu. Data panel di perlukan karena merupakan gabungan dari data cross section dan time series. Keuntungan yang di dapat ketika menggunakan data panel di antaranya, data lebih informatif, lebih bervariasi, lebih efisien, dapat menghindari masalah multikolinearitas, lebih unggul dalam mempelajari perubahan yang dinamis, lebih dapat mengukur pengaruh-pengaruh yang tidak dapat di observasi pada data cross section dan time series, serta dengan membuat data tersedia dalam jumlah yang lebih banyak data panel dapat meminimumkan bias yang dapat terjadi bila mengagregatkan individu ke dalam agregat yang luas [2].

Regresi data panel memiliki tiga pendekatan yaitu common effect model, fixed effect model dan random effect model. Fixed effect model adalah model regresi data panel yang menggunakan variabel dummy untuk mengetahui perbedaan karakteristik, baik antar individu maupun antar waktu. Penerapan regresi data panel sebagai salah satu metode untuk mengetahui perbedaan karakteristik dapat juga diterapkan untuk menganalisis indeks pembangunan manusia [1].

Keberhasilan pembangunan dari suatu negara dapat dinilai dari pertumbuhan ekonominya. Tetapi pertumbuhan ekonomi juga perlu diukur dari banyak aspek kegiatan ekonomi yang berlaku misalnya perkembangan pendidikan, teknologi, peningkatan kesehatan, infrastruktur, pendapatan dan kemakmuran. Salah satu tolak ukur pembangunan manusia dapat dipandang dari indeks pembangunan manusia (IPM) yang bertujuan untuk meningkatkan kualitas hidup manusia. Indeks pembangunan manusia dibangun dengan tiga dimensi yaitu dimensi kesehatan, dimensi pendidikan serta dimensi standar layak hidup [3]. Dimensi kesehatan diukur menggunakan angka harapan hidup. Dimensi pendidikan diukur menggunakan harapan lama sekolah dan rata-rata lama sekolah. Sedangkan dimensi standar layak hidup diukur menggunakan pengeluaran per kapita riil dalam rupiah [4].

\section{B. Metodologi Penelitian}

\section{Regresi Data Panel}

Data panel adalah gabungan dari cross-section dan time series, dengan istilah lain data pada tabel terdiri berdasarkan beberapa objek dan meliputi beberapa waktu. Metode data panel bertujuan untuk menerima output perkiraan yang lebih baik menggunakan bertambahnya jumlah pengamatan, yaitu menggunakan bertambahnya derajat kebebasan [5].

Data time series adalah data untuk objek yang terdiri beberapa periode waktu. Data ini umumnya tersaji pada format sebagai berikut: tahunan, bulanan, triwulanan, mingguan, harian dan lain sebagainya. Oleh karena itu, pada pembuatannya perlu diperhatikan urutannya. Data cross-section adalah data dari beberapa entitas selama periode waktu tertentu. Data crosssection mengacu dalam data yang dikumpulkan menggunakan pengamatan banyak hal misalnya, individu, perusahaan, negara, wilayah dan lain sebagainya. Menganalisis data crosssection sering kali membandingkan perbedaan antara subyek. Oleh karena itu urutan data tidak mempengaruhi hasil analisis [6].

Dalam model data panel persamaan model dengan menggunakan data cross-section dapat ditulis sebagai berikut [3]:

$$
Y_{i}=\beta_{0}+\beta_{1} X_{i}+\cdots+\varepsilon_{i} ; i=1,2, \ldots, N
$$

Di mana $N$ adalah banyaknya data cross-section

Sedangkan persamaan model dengan time series adalah:

$$
Y_{t}=\beta_{0}+\beta_{1} X_{t}+\cdots+\varepsilon_{t} ; t=1,2, \ldots, T
$$

Di mana $T$ adalah banyaknya data time series

Oleh karena data panel merupakan gabungan antara data time series dan cross-section, 
maka persamaan yang dapat ditulis adalah

Dimana:

$$
Y_{i t}=\beta_{0}+\beta_{1} X_{i t}+\cdots+\varepsilon_{i t} ; i=1,2, \ldots, N \text { dan } t=1,2, \ldots, T
$$

$\beta_{0}$ : parameter untuk variabel ke-0

$\beta_{1}$ : parameter untuk variabel ke- 1

$X_{i t}$ : variabel bebas individu ke- $i$ pada waktu ke- $t$

$\varepsilon_{i t}$ : Komponen error untuk individu ke- $i$ pada waktu ke- $t$

$N$ : banyaknya observasi

$T$ : banyaknya waktu

$N$ x $T$ : banyaknya data panel

Untuk mengestimasi parameter model dengan data panel, terdapat beberapa teknik di antaranya:

\section{Common Effect Model}

CEM adalah teknik yang paling sederhana dalam mengestimasi data panel dengan cara menggabungkan data time series dan cross-section. Pendekatan ini tidak memperhitungkan dimensi antara individu dan waktu karena pada pendekatan ini dapat diasumsikan bahwa data perilaku antar individu sama dengan kurun waktu [7]. Persamaan metode ini dapat dirumuskan sebagai berikut [5]:

Dimana:

$$
Y_{i t}=\alpha+\beta_{j} X_{i t}^{j}+\varepsilon_{i t}
$$

$Y_{i t}$ : Variabel terikat individu ke- $i$ pada waktu ke- $t$

$X_{i t}^{j}$ : Variabel bebas ke- $j$ individu ke- $i$ pada waktu ke- $t$

$i$ : Unit cross-section sebanyak $N$

$j$ : Unit tine series sebanyak $T$

$\varepsilon_{i t}:$ Komponen error individu ke- $i$ pada tahun ke- $t$

$\alpha:$ Intersep

$\beta_{j}$ : Parameter untuk variabel ke-j

\section{Fixed Effect Model}

Model ini digunakan untuk mengatasi kelemahan dari analisis data panel yang menggunakan metode common effect, Karena pada pendekatan CEM intersep yang di hasilkan tidak berubah baik antar individu maupun waktu. Maka model FEM ini akan mengatasi permasalahan tersebut dengan menunjukkan perbedaan konstanta antar objek, meskipun dengan koefisien regresor yang sama [5].

Asumsi dalam model ini yaitu dengan adanya perbedaan intersep antar objek namun intersep antar waktunya sama. Selain itu metode ini juga mengasumsikan bahwa slopenya sama antar objek maupun antar waktu [5]. Maka ditambahkan generalisasi secara umum yang sering dilakukan adalah dengan memasukkan variabel dummy untuk mengizinkan terjadinya perbedaan nilai parameter yang berbeda-beda baik lintas unit cross-section maupun antar waktu [6]. Formula dapat dirumuskan sebagai berikut [5]:

$$
Y_{i t}=\alpha_{i}+\beta_{j} X_{i t}^{j}+\sum_{i=2}^{n} \alpha_{i} D_{i}+\varepsilon_{i t}
$$

Dimana:

$Y_{i t}$ : Variabel terikat untuk individu ke-i pada waktu ke-t

$X_{i t}^{j}$ : Variabel bebas ke-j untuk individu ke-i pada waktu ke-t

$D_{i}$ : Variabel dummy

$\varepsilon_{i t}:$ Komponen error untuk individu ke- $i$ pada waktu ke- $t$

$\alpha_{i}$ : intersep individu ke- $i$

$\beta_{j}$ : Parameter untuk variabel ke-j 


\section{Random Effect Model}

Model ini digunakan untuk memilih estimasi data panel di mana residual mungkin saling berhubungan antar waktu dan individu. Metode ini juga memiliki perbedaan intersep antar objek dan antar waktu yang mungkin terjadi yang kemudian akan dimasukkan ke dalam error pada suatu model OLS, sehingga model akan efisien [6]. Parameter-parameter yang memiliki perbedaan antar objek maupun waktu juga akan dimasukkan ke dalam error. Oleh karena itu, model ini juga sering disebut dengan model komponen error [8]. Persamaan REM dapat dirumuskan sebagai berikut [5]:

Dimana:

$$
Y_{i t}=\alpha+\beta_{j} X_{i t}^{j}+\varepsilon_{i t} ; \varepsilon_{i t}=u_{i}+V_{t}+W_{i t}
$$

$\beta_{j}$ : Parameter untuk variabel ke- $j$

$X_{i t}^{j}$ : Variabel bebas ke-j untuk individu ke- $i$ pada waktu ke- $t$

$\varepsilon_{i t}$ : Komponen error untuk individu ke- $i$ pada waktu ke- $t$

$\alpha_{i}:$ intersep

$u_{i}:$ Komponen error cross-section

$V_{t}:$ Komponen error time series

$W_{i t}:$ Komponen error gabungan

\section{Pemilihan Model Regresi Data Panel}

Pemilihan model regresi dapat dilakukan dengan cara melakukan pengujian di antaranya:

1. Uji chow

Uji chow digunakan untuk memilih kedua model diantara model common effect dan model fixed effect melalui nilai residual sum squares. Uji chow juga dapat dilakukan dengan hipotesis sebagai berikut [9]:

Hipotesis:

$H_{0}:$ common effect model

$H_{1}:$ fixed effect model

Kriteria:

Menerima $H_{0}$ jika cross-section F nilai probabilitasnya > alpha 5\% $(0,05)$.

Menerima $H_{1}$ jika cross-section F nilai probabilitasnya < alpha 5\% $(0,05)$.

2. Uji Hausman

Uji Hausman digunakan untuk memilih kedua model diantara model fixed effect dan random effect. Uji Hausman juga dapat dilakukan dengan hipotesis sebagai berikut [9]: Hipotesis:

$H_{0}$ : random effect model

$H_{1}$ : fixed effect model

Kriteria:

Menerima $H_{0}$ jika nilai probabilitas > alpha $5 \%(0,05)$.

Menerima $H_{1}$ jika nilai probabilitas < alpha $5 \%(0,05)$.

\section{Pengujian Signifikansi Parameter}

Uji signifikansi parameter bertujuan untuk menguji apakah koefisien regresi yang diperoleh signifikan atau tidak.

1. Uji Simultan

Uji simultan bertujuan untuk mengetahui pengaruh semua variabel bebas terhadap variabel terikat.

Hipotesis :

$H_{0}$ : seluruh variabel bebas tidak berpengaruh signifikan secara simultan terhadap variabel terikat

$H_{1}$ : seluruh variabel bebas berpengaruh signifikan secara simultan terhadap variabel terikat

Uji simultan dapat dilakukan dengan membandingkan $\mathrm{F}$ hitung, jika $\mathrm{F}$ hitung $>\mathrm{F}$ tabel $\left(F_{(\alpha,(K-1),(K T-K-1))}\right)$ maka $H_{1}$ diterima dan $H_{0}$ ditolak. Sebaliknya jika $\mathrm{F}$ hitung $<\mathrm{F}$ 
tabel $\left(F_{(\alpha,(K-1),(K T-K-1))}\right)$ maka $H_{1}$ ditolak dan $H_{0}$ diterima. Selain itu, uji $\mathrm{F}$ dapat dilakukan dengan membandingkan nilai signifikansi (Prob(F-statistic)). Jika nilai signifikansi $>\alpha(0,05)$ maka $H_{0}$ diterima dan $H_{1}$ ditolak. Sebaliknya jika nilai signifikansi $<\alpha(0,05)$ maka $H_{0}$ ditolak dan $H_{1}$ diterima [10].

2. Uji Parsial

Uji parsial bertujuan untuk mengetahui signifikansi variabel bebas secara individu terhadap variabel terikat.

Hipotesis:

$H_{0}: \beta_{j}=0$ artinya terdapat pengaruh tidak signifikan antara variabel bebas terhadap variabel terikat

$H_{1}: \beta_{j} \neq 0$ artinya terdapat pengaruh yang signifikan antara variabel bebas terhadap variabel terikat.

Uji parsial dapat dilakukan dengan membandingkan $\mathrm{t}$ hitung, jika t hitung $>\mathrm{t}$ tabel $\left(t_{(\alpha,(n-K-1))}\right)$ maka $H_{0}$ ditolak. Sebaliknya jika t hitung < t tabel $\left(t_{(\alpha,(n-K-1))}\right)$ maka $H_{0}$ diterima. Selain itu uji t dapat dilakukan dengan membandingkan nilai probabilitasnya. Jika nilai probabilitas $>\alpha(0,05)$ maka $H_{0}$ diterima. Sebaliknya jika nilai probabilitas < $\alpha(0,05)$ maka $H_{0}$ ditolak [6].

\section{Uji Asumsi Klasik}

Model regresi data panel dapat disebut sebagai model yang baik jika model tersebut memenuhi kriteria Best, Linear, Unbiased dan estimator (BLUE) [5]. Kondisi ini akan terjadi jika dipenuhi beberapa asumsi, yang disebut dengan asumsi klasik [11].

1. Uji Normalitas

Uji normalitas adalah model regresi yang bertujuan untuk menguji apakah variabel dependen dan atau independen berdistribusi normal. Deteksi normalitas dilakukan dengan melihat grafik probailitas normal dengan menggunakan metode jarque bera pada aplikasi eviews10. Jika nilai probabilitas lebih besar dari 0,05 (signifikansi), maka data berdistribusi normal dan sebaliknya [10].

2. Uji Multikolinearitas

Uji multikolinearitas dimaksudkan untuk menguji apakah terdapat hubungan linier antara beberapa atau semua variabel yang menggambarkan model regresi. Uji multikolinearitas dilakukan dengan menguji matriks korelasi antar variabel independen. Jika koefisien korelasi antar variabel independen adalah 0,8 atau lebih besar, maka data tersebut didefinisikan sebagai multikolinearitas [12].

3. Uji Autokorelasi

Uji autokorelasi bertujuan untuk menguji apakah terdapat korelasi antara anggota serangkaian observasi yang diurutkan menurut waktu seperti data time series atau ruang seperti cross-section. Autokorelasi dapat dilihat dengan metode serial correlation. Apabila nilai probabilitasnya lebih kecil dari 0,05 (nilai signifikansi) maka dapat dikatakan terjadi masalah autokorelasi [12].

4. Uji Heteroskedastisitas

Uji ini bertujuan untuk menguji apakah model regresi terjadi ketidaksamaan varian dari residual satu pengamatan ke pengamatan yang lain. Heteroskedasisitas dapat dilihat dengan menggunakan metode white. Apabila nilai probabilitasnya lebih kecil dari 0,05 (nilai signifikansi) maka terdapat masalah heteroskedastisitas [10].

\section{Uji Kebaikan Model Regresi Data Panel}

Keofisien determinasi $\left(R^{2}\right)$ adalah suatu nilai yang menunjukkan besarnya perubahan yang terjadi diakibatkan oleh variabel lainnya. Koefisien determinasi digunakan untuk mengetahui persentase besarnya keterkaitan antara variabel bebas terhadap variabel terikat [5]. Koefisien determinasi dilakukan untuk mengetahui seberapa jauh variasi variabel independen dapat menerangkan dengan baik variasi variabel dependen [11].

Nilai koefisien determinasi berkisar antara satu dan nol. nilai koefisien determinasi yang 
kecil artinya kemampuan variabel bebasnya dalam menjelaskan variabel terikat sangat terbatas, begitu pula sebaliknya [5].

\section{Indeks Pembangunan Manusia}

Indeks pembangunan manusia memiliki dua aspek, yang pertama adalah pembentukan kapasitas manusia seperti kesehatan, pendidikan dan peningkatan kapasitas. Kedua, menikmati waktu luang dan menggunakan kemampuan produktif dalam kegiatan budaya, sosial dan politik. Ketidakstabilan dapat terjadi jika skala pembangunan manusia seimbang. Evolusi manusia harus fokus pada pembangunan manusia, bukan hanya perluasan pendapatan dan kesejahteraan [12].

\section{Angka Harapan Hidup}

Angka harapan hidup didefinisikan sebagai rata-rata perkiraan banyak tahun yang dapat ditempuh oleh seseorang sejak lahir. Angka harapan hidup mencerminkan derajat kesehatan suatu masyarakat, sumber data yang digunakan dalam perhitungan angka harapan hidup dihitung dari hasil proyeksi sensus penduduk [4].

\section{Harapan Lama Sekolah}

Angka harapan lama sekolah dapat didefinisikan sebagai lamanya pendidikan (tahun) yang diharapkan dapat dialami oleh anak-anak pada usia tertentu di masa depan. Harapan lama sekolah dapat dihitung dari usia 7 tahun ke atas berdasarkan kebijakan wajib belajar pemerintah [4].

\section{Rata-Rata Lama Sekolah}

Rata-rata lama sekolah dapat didefinisikan sebagai periode waktu yang digunakan oleh penduduk ketika mereka di didik secara formal. Rata-rata lama sekolah dihitung untuk usia 25 tahun ke atas dengan asumsi bahwa pada umur 25 tahun proses pendidikan sudah berakhir. Perhitungan tersebut juga mengikuti standar internasional yang di gunakan oleh UNDP [4].

\section{Pengeluaran Per kapita}

Pengeluaran per kapita merupakan biaya yang dikeluarkan untuk konsumsi semua anggota rumah tangga selama sebulan. Manusia tidak perlu sumber daya keuangan yang berlebihan untuk memastikan kehidupan yang layak. Aspek ini diperhitungkan dengan menggunakan logaritma pengeluaran per kapita yang mencerminkan indikator pendapatan/pengeluaran [10].

\section{Hasil Penelitian dan Pembahasan}

\section{Data Penelitian}

penelitian ini menggunakan data tahunan dari tahun 2016 sampai 2020 yang terdiri dari angka harapan hidup (X1), harapan lama sekolah (X2), rata-rata lama sekolah (X3), pengeluaran per kapita (X4) dan indeks pembangunan manusia (Y) di kota provinsi jawa barat. Data angka harapan hidup, harapan lama sekolah, rata-rata lama sekolah, pengeluaran per kapita dan indeks pembangunan manusia diperoleh dari website jabar.bps.go.id. pada penelitian ini data yang telah diperoleh diolah menggunakan sofeware Eviews 10.

\section{Hasil Penelitian}

1. Pemilihan Model Regresi Data Panel. 
Tabel 1. Uji Chow

\begin{tabular}{|c|c|c|c|}
\hline Effect Test & \multicolumn{1}{|c|}{ Statistic } & d.f. & Prob. \\
\hline Cross-section F & 6,2211294 & $(8,32)$ & 0,0001 \\
& & & \\
\hline Cross-section Chi-square & 42,218048 & 8 & 0,0000 \\
\hline
\end{tabular}

Sumber : data diolah menggunakan eviews10

Tabel 2. Uji Hausman

\begin{tabular}{|l|l|l|l|}
\hline Test Summary & Chi-Sq. Statistic & Chi-Sq. d.f. & Prob. \\
\hline Cross-section random & 43,477335 & 4 & 0,0000 \\
\hline
\end{tabular}

Sumber : data diolah menggunakan eviews10

a. Uji Chow

Pada tabel 1 dapat dilihat bahwa nilai probabilitas cross-section $\mathrm{F}$ sebesar 0,0001 dan nilainya lebih kecil dari 0,05 maka $H_{1}$ diterima. Dengan $H_{1}$ diterima maka fixed effect model yang digunakan. Untuk itu dilanjutkan dengan uji hausman untuk membandingkan antara fixed effect model dengan random effect model.

b. Uji Hausman

Pada tabel 2 dapat dilihat bahwa nilai probabilitas sebesar 0,0000 dan nilainya lebih kecil dari 0,05 maka $H_{1}$ diterima. Dengan $H_{1}$ diterima maka fixed effect model yang digunakan. Untuk itu tidak perlu dilanjutkan dengan uji lagrange multiplier untuk membandingkan antara random effect model dengan common effect model. Berikut adalah hasil estimasi fixed effect model (FEM).

Tabel 3. Random effect model

\begin{tabular}{ccccc}
\hline Variable & Coefficient & Std. Error & t-Statistic & Prob. \\
\hline $\mathbf{C}$ & 0,190865 & 0,122542 & 1,557547 & 0,1292 \\
$\mathbf{X 1}$ & 0,488695 & 0,033775 & 14,46931 & 0,0000 \\
$\mathbf{X 2}$ & 0,146783 & 0,006900 & 21,27369 & 0,0000 \\
$\mathbf{X 3}$ & 0,158318 & 0,004556 & 34,74717 & 0,0000 \\
$\mathbf{X 4}$ & 0,137784 & 0,002196 & 62,73925 & 0,0000 \\
\hline
\end{tabular}

Sumber : data diolah menggunakan eviews10

Tabel 4. common effect model

\begin{tabular}{cc}
\hline Cross section & Effect \\
\hline Bogor & -0.001545 \\
Sukabumi & 0.000692
\end{tabular}




$\begin{array}{cc}\text { Bandung } & 0.001332 \\ \text { Cirebon } & -0.001772 \\ \text { Bekasi } & 0.000658 \\ \text { Depok } & -0.001658 \\ \text { Cimahi } & -0.000618 \\ \text { Tasikmalaya } & 0.001458 \\ \text { Banjar } & 0.001453\end{array}$

Sumber : data diolah menggunakan eviews 10

$$
\begin{gathered}
Y_{i t}=\alpha_{i}+\beta_{j} X_{i t}^{j}+\sum_{i=2}^{n} \alpha_{i} D_{i}+\varepsilon_{i t} \\
Y_{i t}=\alpha_{i}+0,488695 X_{1}+0,146783 X_{2}+0,158318 X_{3}+0,137784 X_{4}
\end{gathered}
$$

2. Pengujian Signifikansi Parameter

Tabel 5. Uji Simultan

\begin{tabular}{|c|c|}
\hline Prob(F-statistic) & 0,000000 \\
\hline F-statistic & 148615,7 \\
\hline
\end{tabular}

Sumber : data diolah menggunakan eviews 10

Tabel 6. Uji Parsial

\begin{tabular}{|c|c|}
\hline Variable & Prob. \\
\hline $\mathbf{X 1}$ & 0,0000 \\
\hline $\mathbf{X 2}$ & 0,0000 \\
\hline $\mathbf{X 3}$ & 0,0000 \\
\hline $\mathbf{X 4}$ & 0,0000 \\
\hline
\end{tabular}

Sumber : data diolah menggunakan eviews 10

a. Uji Simultan

Pada tabel 3 dapat dilihat bahwa nilai Prob(F-statistic) sebesar 0,000000 artinya nilai Prob(F-statistic) $<\alpha(0,05)$ maka $H_{0}$ ditolak. Maka dapat disimpulkan bahwa semua variabel bebas berpengaruh signifikan secara simultan terhadap variabel terikat.

b. Uji Parsial

Pada tabel 4 dapat dilihat bahwa nilai probabilitas angka harapan hidup sebesar 0,0000 artinya nilai probabilitas $<\alpha(0,05)$ maka $H_{0}$ ditolak. Nilai probabilitas harapan lama sekolah sebesar 0,0000 artinya nilai probabilitas $<\alpha(0,05)$ maka $H_{0}$ ditolak. Nilai probabilitas rata-rata lama sekolah sebesar 0,0000 artinya nilai probabilitas $<\alpha(0,05)$ maka $H_{0}$ ditolak. Nilai probabilitas pengeluaran per kapita sebesar 0,0000 artinya nilai probabilitas $<\alpha(0,05)$ maka $H_{0}$ ditolak. Maka dapat disimpulkan bahwa angka harapan 
hidup, harapan lama sekolah, rata-rata lama sekolah dan pengeluaran per kapita masingmasing memiliki pengaruh yang signifikan terhadap indeks pembangunan manusia.

3. Uji Asumsi Klasik

Uji asumsi klasik terdiri dari uji normalitas, uji multikolinearitas, uji autokorelasi dan uji heteroskedastisitas. Regresi data panel dapat dikatakan baik digunakan jika memenuhi uji asumsi klasik. Hasil dari uji asumsi klasik dapat disimpulkan bahwa model regresi data panel dengan menggunakan pendekatan fixed effect model memenuhi semua kriteria uji asumsi klasik, maka model ini baik untuk digunakan.

4. Koefisien Determinasi

Tabel 7. Koefisien Determinasi

\begin{tabular}{lc}
\hline Adjusted R-squared & 0,999975 \\
\hline R-squared & 0,999982
\end{tabular}

Sumber : data diolah menggunakan eviews10

Nilai koefisien determinasi yang didapatkan adalah sebesar 0,999975 atau sebesar 99,99\%. Artinya 99,99\% dari indeks pembangunan manusia dapat dijelaskan oleh variabel angka harapan hidup, harapan lama sekolah, rata-rata lama sekolah dan pengeluaran per kapita. Karena nilai R-squared sebesar 0,999982 maka model yang dikeluarkan oleh regresi data panel baik untuk digunakan.

\section{Kesimpulan}

Berdasarkan pengujian statistik dengan menggunakan data panel maka dapat disimpulkan bahwa angka harapan hidup, harapan lama sekolah, rata-rata lama sekolah dan pengeluaran per kapita memiliki pengaruh yang signifikan terhadap indeks pembangunan manusia. Model yang baik digunakan dalam penelitian ini yaitu fixed effect model.

\section{Daftar Pustaka}

[1] N. P. A. M. Ratnasari, I. P. E. N. Kencana dan G. K. Gandhiadi, "Aplikasi Regresi Data Panel dengan Menggunakan Pendekatan Fixed Effect Model (Studi Kasus: PT PLN Gianyar)," E-Jurnal Matematika, vol. 3, no. 1, pp. 1-2, 2014.

[2] A. M. Astuti, "Fixed Effect Model Pada Regresi Data Panel," Beta, vol. 3, no. 2, pp. 134$135,2010$.

[3] A. Melliana dan I. Zain, "Analisis Statistika Faktor yang Mempengaruhi Indeks Pembangunan Manuisa Di Kabupaten/Kota Provinsi Jawa Timur dengan Menggunakan Regresi Panel," Jurnal Sains dan Seni Pomits, vol. 2, no. 2, 2013.

[4] B. P. S. P. J. Barat, Indeks Pembangunan Manusia Provinsi Jawa Barat 2020, Bandung: Badan Pusat Statistik Provinsi Jawa Barat, 2021.

[5] D. Silalahi, R. Sitepu dan G. Tarigan, "Analisis Ketahanan Pangan Provinsi Sumatera Utara Dengan Metode Regresi Data Panel," Jurnal Saintia Matematika, vol. 02, no. 03, pp. 239244, 2014.

[6] Nuryanto dan Z. B. Pambuko, Eviews Untuk Analisis Ekonometrika Dasar, Magelang: UNIMMA PRESS, 2018.

[7] A. Lestari dan Y. Setyawan, "Analisis Regresi Data Panel untuk Mengetahui Faktor yang Mempengaruhi Belanja Daerah Di Provinsi Jawa Tengah,” Jurnal Statistika Industri dan Komputasi, vol. 2, no. 1, pp. 3-4, 2017.

[8] M. Sri Hardianti, M. dan A. Prahutama, "Metode Regresi Data Panel Untuk Peramalan Konsumsi Energi Di Indonesia," Jurnal Gaussian, vol. 5, no. 3, p. 477, 2016.

[9] A. P. Sugiantari dan I. N. Budiantara, "Analisis Faktor-Faktor yang Mempengaruhi Angka 
Harapan Hidup di Jawa Timur Menggunakan Regresi Semiparametrik Spline,” Jurnal Sains dan Seni Pomits, vol. 2, no. 1, p. 37, 2013.

[10] R. Muda, R. Koleangan dan J. B. Kalangi, "Pengaruh Angka Harapan Hidup, Tingkat Pendidikan dan Pengeluaran Perkapita Terhadap Pertumbuhan Ekonomi di Sulawesi Utara Pada Tahun 2003-2017," Jurnal Berkala Ilmiah Efisiensi, vol. 19, no. 1, p. 48, 2019.

[11] A. M. Kahar, "Analisis Angka Harapan Lama Sekolah di Indonesia Timur Menggunakan Weighted Least Squares Regression," Jurnal Matematika, vol. 4, no. 1, pp. 32-34, 2018.

[12] N. Dewi, Y. Yusuf dan R. Y. Iyan, "Pengaruh Kemiskinan dan Pertumbuhan Ekonomi terhadap Indeks Pembangunan Manusia di Provinsi Riau," JOM Fekon, vol. 4, no. 1, pp. 870-880, 2017. 